\title{
Information Literacy: A Community Service-Learning Approach
}

\author{
Eugene J. Rathswohl \\ University of San Diego, San Diego, CA, USA \\ gener@sandiego.edu
}

\begin{abstract}
Business, academic, and government leaders have spoken out for professional education to integrate solid knowledge and skills with a spirit of volunteerism and community service (Briscoe, 1998; Hayes, 1997; Small/Venkatesh, 1998). This paper describes an example of how community service-learning has been applied in an information systems course required in a Bachelor of Business Administration degree.
\end{abstract}

Keywords: information systems, teaching, community service-learning, information literacy

\section{Introduction}

Several years ago, the University of San Diego's administrators and faculty saw increased student community service as one way to put the University's values into action. A Community Service-Learning Office was established on campus to initiate, promote, and coordinate service-learning activities. An Advisory Committee comprised of faculty, students, and community partners built upon existing collaborative efforts to plan for integrating community service-learning into academic study. Subsequently, USD received a Corporation for National Service "Learn and Serve America: Higher Education Enhancement" grant in the fall of 1994 to help put that plan into action.

The overall vision of community service-learning at USD is of care, commitment, and concern that are put into action by students, faculty, and staff who combine service and learning in projects that respond to real needs as identified by the community. Several campus-based student organizations, clubs, fraternities and sororities sponsor ongoing community projects coordinated by student leaders. Community projects are sponsored also through other campus organizations, such as the Social Issues Committee and University Ministry.

Course-based service-learning is a very large component of service-learning at USD. Over 55 faculty persons campus-wide have integrated service-learning into approximately 100 courses. Approximately 35 such courses are offered each semester. Student/faculty teams facilitate these service-learning experi-

Material published as part of this journal, either on-line or in print, is copyrighted by the publisher of Informing Science. Permission to make digital or paper copy of part or all of these works for personal or classroom use is granted without fee provided that the copies are not made or distributed for profit or commercial advantage AND that copies 1) bear this notice in full and 2) give the full citation on the first page. It is permissible to abstract these works so long as credit is given. To copy in all other cases or to republish or to post on a server or to redistribute to lists requires specific permission and payment of a fee. Contact Editor@inform.nu to request redistribution permission. ences for over 1000 students each year.

A special feature of USD's course-based servicelearning is the faculty/student/community partner team approach. Each team member has certain responsibilities. Faculty members participate in curriculum development workshops, revise their course curriculum to include service-learning, and work closely with a student leader chosen from their class. Student leaders link with faculty to provide service-learning information and to offer support to their classmates; they enroll in a field 
experience leadership seminar to enhance their theoretical understanding and practical skills. Community partners include schools, agencies, companies, and organizations; they provide placements for USD students and a person who serves as liaison to USD and helps the community partner become an extension of the classroom.

\section{BUS 86 - Information Systems}

The following is a description of applying community service-learning in the undergraduate information systems course required for the Bachelor of Business Administration degree at USD.

\section{Course Objectives - Information Literacy}

The emphasis of the course is to help the student: a) develop problem solving and communications hands-on skills using microcomputer software and the Internet; b) understand terminology, concepts, technologies, services, and trends in the information industry; and c) understand his/her role as an enduser in the system development process.

An important learning objective of the course is to develop information literacy skills from the perspective of the student as an end-user or client of information services available to them as a business professional. Two types of skills are important for information literacy: conceptual skills and practical, handson skills.

Conceptual skills comprise a student's (client's) information style and his/her ability for reflexive thinking. A client's information style is the person's conceptual framework for defining their own information requirements and how to go about searching for and using available information resources. Some information literacy research emphasizes that information behavior is a determinate process, that there are optimum, efficient ways of defining one's information needs, and then searching for and using that information. But many work situations are highly semi-structured and require the client to articulate information needs and search strategies on his/her own. The second conceptual literacy skill - reflexive thinking - is the ability of a client to be aware of his/her own information behavior. If users are responsible for developing their own information style they should be able to articulate the various aspects of the information environment and their perceived information environment that facilitate or impede their information behavior. A client must be conscious of information as problematic in order to manage his/her own information behavior.

Practical, hands-on skills comprise being able to use information tools of a particular information resource, such as a spreadsheet or an Internet search engine/directory, and being able to utilize, in a coordinated way, information tools amongst a variety of information resources, such as using a software suite

\section{Course Design}

The BUS86 information systems course is a required, lower division course for the Bachelor of Business Administration degree. The course is divided into five modules, each approximately three weeks duration. Each module focuses on a particular theme and information literacy skill set. Module 1 includes coverage of Windows, e-mail, software basics, and Netscape; Module 2 is hardware basics, word processing software, MS Word and MS PowerPoint; Module 3 looks at decision support software, business graphics, and MS Excel graphics; Module 4 discusses database applications and MS Access; and Module 5 covers networks and electronic commerce topics and Web presentation design. Each module has at least one written assignment and one hands-on software assignment. Three exams are scheduled during the semester as well. 
In addition to the standard course requirements, students participate in a project in conjunction with the USD Office for Community Service-Learning. The community service-learning component of the course involves at least ten hours outside class time working with high school students in computeroriented classes at Kearny High School. Kearny High is one of five "Partnership in Education" schools that link with USD in the 5-mile radius adjoining Linda Vista neighborhood; the other schools are Carson elementary, Linda vista Elementary, Montgomery Academy, and Twain Junior/Senior High. Kearny High has over 1,400 students who reflect the cultural diversity of the Linda Vista area. The students' ethnic diversity (white, Latino, Asian, and African-American) is one of the strengths of the overall school program and the important dimension of the USD students' community service-learning experience. Kearny High serves as a magnet school for industry and technology in the San Diego school district's integration effort. In addition to the information systems course describe here, USD has several other ongoing projects at Kearny High as well, including media literacy workshops, French tutors, and tutoring students in the ESL (English as a Second Language) program.

\section{Preparing and Implementing the Service-Learning Component in the Course}

The author has included community service-learning with Kearny High School since the Fall 1998 semester. Approximately 120 students have participated. The preparation and implementation for servicelearning is accomplished in several phases each semester.

\section{Phase 1: Initial Contact with Kearny High School}

Kearny High School offers several computer-oriented courses. Several sections of the basic computer literacy course are offered each semester during the day for the full-time high school students, and in the evening for continuing education adults. Other courses incorporating the use of personal computers are offered periodically including an accounting course and a small business course that utilize spreadsheet software, and a keyboarding/word processing class for special education students. Also during the spring semester, each senior is required to finalize his/her portfolio that includes a PowerPoint presentation and possibly other computer-based work. Each of the courses is conducted in a computer lab/classroom with approximately $25 \mathrm{pc}$ workstations, Internet access, and computer projection equipment.

At the beginning of each semester the author has a meeting with the Kearny High business faculty to discuss their needs for USD student assistance. We discuss our mutual interests, responsibilities, and administrative procedures for our collaborative success. We discuss both Kearny and USD students' learning objectives and the students' needs and objectives for a service-learning experience. A schedule is made of all the 2-hour time-slots during the week for the various courses - each time-slot usually can use three or four USD students. We decide on a particular week in the semester to begin and end the service-learning for USD students, usually a six or seven week time span beginning half way through the semester and ending before final exams at the end of the semester.

\section{Phase 2: Connecting the Kearny High Students with the USD Students}

The author discusses community service-learning with the students in his BUS86 class on several occasions during the first few weeks of the semester. Usually a representative from the USD ServiceLearning Office makes a classroom presentation as well. The intent is to reflect on the notion of community service in the context of professional work and to peak students' interest in the value of servicelearning in the context of the information systems course. The author distributes the 2-hour time-slot schedule a couple of weeks before commencing service-learning at Kearny High; each student schedules him/herself for one and the same 2-hour time-slot each week for at least five weeks, for a total of at least 
10 hours. Each student is responsible for scheduling their time appropriately to fit his/her other time commitments.

\section{Phase 3: Working the Service-Learning Experience}

During the first scheduled week of service-learning, each USD student is quickly oriented in the Kearny High computer lab/classroom. Each USD student is assigned to one or more particular Kearny students to work with for the duration of the service-learning experience. It is important to note that USD students are doing service-learning during actual classroom time of the Kearny High students; the Kearny High teacher is conducting the class and the USD students are serving basically as classroom aides. During a 2-hour class session a USD student will typically help the Kearny student go through the lesson plan, provide tips and suggestions, and generally give encouragement and guidance. Stretching the service-learning experience over a period of at least five weeks enables the USD and Kearny students to get to know each other that results in mutual benefits. Each USD student is required to maintain a journal, recording after each 2-hour session his/her comments regarding what service was provided, what was learned, and insights regarding the cultural and diversity issues experienced.

\section{Phase 4: Reporting and Evaluation}

During the last week of the semester the author devotes a class period for discussing and reflecting on the service-learning experience for that semester. A representative from the USD Community ServiceLearning Office leads the reflection discussion that besides reviewing the successes and difficulties of the semester, also engages the students in thinking about the broader ethical and cultural issues of information systems. Last semester a case study (Shanks, 2000) was used very effectively to guide the reflection discussion.

Each USD student also is required to compose a written final reflection paper, summarizing his/her service-learning experience. In the paper, each student is to evaluate his/her experience in each of the three community service-learning components - reflections on the cultural/community issues he/she experienced, reflections on the service he/she provided, and reflections on what he/she learned about information systems

An important learning objective for USD students is to learn how to interact and communicate with clients in a real-world setting. Many of the students commented in their reflection papers on the difficulties, surprises, and ultimate gratification of working with high school and adult learners (clients) from much different social/economic situations than their own.

\section{How Community Service-Learning Affects Students}

There are many measures for any educational pedagogy. Several studies show that service-learning pedagogy has significant positive effects on student GPA, writing and critical thinking skills, commitment to activism and racial understanding, interpersonal and leadership skills, and choice of a serviceoriented career (Astin, et.al, 2000; Sax, et.al., 1997). The emphasis was to incorporate community service-learning into the design and conduct of the course, with cultural pluralism as a secondary spin-off. The basic community service-learning model emphasizes work on a volunteer basis; the course used a client-consulting model to define the work relationship between the USD students (the consultants) and the Kearny High students (the clients). Whereas the volunteer model emphasizes contributing one's talents and services to an on-going program, the client consulting model emphasizes the role of a consultant as a change agent for the organization, who can organize an activity or project based on the values of the clients and the clients' organization and achieve stated goals and objectives within agreed upon time and resource constraints. Having the USD students work as consultants (paid with a course grade) to a 
non-profit service-oriented organization (a public high school) provided them a valuable opportunity to develop practical communication skills and valuable insights to the needs and values of the people that these community service organizations serve.

\section{Conclusion}

The following small sample of quotes from several USD students' reflection papers show that the service-learning experience changed the consultants (USD students) as much as, if not more than, the experience changed the clients (Kearny High students).

\section{Service}

"...I had a good time helping the students work through some of the different computer applications and it felt really good to be able to help them. If feels good to share the knowledge that you have learned and to be able to pass it one to others." "... One of the best parts about the service was that we were able to use the knowledge that we had just learned in our Information Systems class. I also learned a little bit while helping the students when I could not answer their questions." "...I was an older, college student for these students to look up to. I think that it is important for young teens to see students, only a few years older than themselves, attending college. It sets a good example and a goal for them to strive for." "...When I began to get to know the students and they became used to seeing me over their shoulders I saw my role changing. I was actually there to help the students learn and ease the burden of the teacher. I would say that I helped the majority of the students at least once, which is better than nothing."

\section{Learning}

“...I enjoyed doing community service that tied into my class experiences, helping me to learn class materials and apply them at the same time, while meeting new, diverse people at the same time." "...The first week set the pace for the following weeks. I realized that I wasn't going to know all of the answers to the questions they asked me. I was going to have to try to help both of use figure it out. That part was both exciting and scary." "...community service-learning served as a great reminder to me that information systems is truly the new issue of the present as well as the future. I have come to the realization that information systems can go beyond the general use of technical support. It acts as a simple link between the different classification of society in the business and the social world."

\section{Community and Social Responsibility}

“... This project helped me to learn things about myself, as well as helping the students of the class. I learned that I have the ability to help people, and I need to use that ability more than I already do." "...This experience was valuable for me because I could see that there are people in this world that are a lot less fortunate than me and that I should be grateful for everything that I have... I have a lot more respect for people who are different from me." "...Many students struggle with declaring a major and deciding future career goals. Community service-learning could help spark an interest in students that they never knew existed." "...I think many times people forget that this [USD] is a Catholic university, but when they go out and really help people in need, it can help them to remember, feel, and experience first hand Christian values that they hold deep in their hearts. I understand this now from my experiences of participating in service learning." 


\section{Acknowledgment}

Special thanks to the Kearny High School faculty who have graciously welcomed USD students into their classes, especially Peggy MacArthur, and Scott Waid, Connie Ewens, Bruce Hartley, Brent Steinman, and David Thompson.

\section{References}

Astin, A.W, Vogelgesang, L.J., Ikeda, E.K., \& Lee, J.A. (2000). How service learning affects students - Executive summary. Higher Education Research Institute, University of California, Los Angeles, CA. http://www.gseis.ucla.edu/slc/rhowas.html

Briscoe, D. (1998). What matters most: Enhancing the quality of our human ties through service - learning. Professional unpaid service to the community: Why do we do it, how does it contribute to our profession, and why should we encourage our students to do it? Paper presented at Academy of Management. San Diego, CA. August.

Hayes, A.B. (1997). The mutual gifts of service learning. Trusteeship. Association of Governing Boards of Universities and Colleges. http://www.sandiego.edu/president/service.html

Sax, L.J. \& Astin, A.W. (1997). The benefits of service: Evidence from undergraduates. Educational Record, 78: 25-32.

Shanks, T. S.J. (2000). The case of the cyber city network. Markkula Center for Applied Ethics, Santa Clara University. http://www.scu.edu/SCU/Centers/Ethics/dialogue/candc/cases/cybercity.shtml

Small, R.V. \& Venkatesh, M. (1998). Linking technology training and community service: An active learning approach. In M. Khosrowpour (Ed.) Effective Utilization and Management of Emerging Information Technologies. 1998 Information Resources Management Association International Conference. Hershey, USA: Idea Group Publishing, pp. 878-881.

Williams, R. (1990). The impact of field education on student development: research findings. In J.C. Kendall and Associates (Ed.) Combining Service and Learning: A Resource Book for Community and Public Service, Vol 1. Raleigh, North Carolina: National Society for Internships and Experiential Education, pp. 130-147.

\section{Biography}

Gene Rathswohl is a faculty member of the University of San Diego where he teaches information systems courses. Prof. Rathswohl has developed recently web site design courses for undergraduate and graduate e-commerce graduate programs. He has authored articles on end-user computing and several textbooks. 